\title{
Analisis Perencanaan Sistem Pendukung Keputusan Menggunakan Simple Additive Weighting (SAW) Dalam Penerimaan Staf Di STMIK Cipta Darma Surakarta
}

\author{
Siti Rihastuti, Afnan Rosyidi \\ STMIK Amikom Surakarta \\ sitirihastuti@gmail.com
}

\begin{abstract}
Abstraksi
STMIK Cipta Darma Surakarta merupakan salah satu perguruan tinggi komputer di Surakarta yang berusaha menyediakan pelayanan administratif yang baik kepada mahasiswa, sehingga pihak manajemen membutuhkan karyawan yang memiliki kemampuan dan kecakapan yang layak untuk mendukung hal tersebut. Penelitian ini dibuat untuk merancang sistem pendukung keputusan untuk membantu bagian PSDM dalam menyeleksi calon staf baru. Pendidikan, usia, pengalaman kerja, nilai ipk, tes tertulis, tes wawancara dan status merupakan kriteria yang digunakan dalam proses penilaian terhadap penerimaan staf yang baru. Metode simple additive weighting (SAW) dipilih karena metode ini memiliki tahapan dalam menentukan perankingan untuk selanjutnya menghasilkan keputusan terbaik berdasarkan beberapa alternatif yang ada. Analisis yang dilakukan menghasilkan urutan nama calon staf baru yang diterima berdasarkan peringkat nilai dari aspek yang dinilai. Sehingga bagian PSDM dapat menentukan nama staf baru yang benar-benar layak diterima.
\end{abstract}

Kata Kunci: sistem pendukung keputusan, simple additive weighting, penerimaan staf

\begin{abstract}
STMIK Cipta Darma Surakarta is one of the computer colleges in Surakarta that trying to provide best administrative services to students, so that management requires employees who have the appropriate abilities dan skills to support this. This research was made to design a decision support system to assist the human resources department in selecting new staff candidates. Education, age, work experience, GPA (grade point average), written test, interview test, and marital status are the criterias used in the assessment process for new staff recruitment. The simple addictive weighting (SAW) method was chosen because this method has stages in determining ranks to then produce the best decision based on several alternatives. The analysis carried out resulted in the order of the names of new staff candidates to be accepted based on the rank of the values of the aspects being assessed. So that the human resources department can determine the names of new staff who really deserve to be accepted.
\end{abstract}

Keywords: decision support system, simple additive weighting, staff aceptance.

\section{PENDAHULUAN}

Lembaga pendidikan yang baik adalah lembaga yang berkualitas dalam hal mengelola sumber daya, mampu bersaing dengan lembaga pendidikan yang lain dan mampu menghasilkan anak didik yang memiliki kemampuan yang sesuai dengan kebutuhan dunia kerja dan industri. Penggunaaan sumber daya yang ada di lembaga pendidikan perlu dioptimalkan untuk menunjang hal tersebut. Salah satu sumber daya yang memiliki peran penting dalam kelancaran penyelenggaran layanan pendidikan bidang administratif adalah sumber daya manusia.
Pengelolaan sumber daya manusia yang baik akan menunjang kelancaran aktivitas pendidikan. Keberlangsungan sebuah lembaga pendidikan salah satunya ditunjang oleh kecakapan manajemen dalam menempatkan karyawan/staf sesuai dengan kemampuan dan keahliannya masing-masing. Pada saat proses penerimaan staf yang baru, tingkat kemampuan calon staf diukur dan dinilai berdasarkan kriteria yang telah ditetapkan oleh manajemen. Manajemen STMIK Cipta Darma telah menetapkan beberapa kriteria saat melakukan proses penilaian penerimaan staf yang baru, yaitu 
pendidikan, usia, pengalaman kerja, nilai ipk, tes tertulis, tes wawancara dan status. 5 (lima) kriteria (pendidikan, usia, pengalaman kerja, nilai ipk, dan status) dinilai berdasarkan seleksi pemberkasan, jika pelamar memenuhi syarat pemberkasan, selanjutnya pelamar menjalani tes tertulis dan tes wawancara. Penilaian ini bertujuan untuk mendapatkan staf yang tepat sesuai dengan jabatan tertentu. Untuk mendapatkan orang yang tepat, penelitian tentang perancangan sistem pendukung keputusan ini menggunakan metode Simple Additive Weighting (SAW). Metode SAW dipilih karena dapat menentukan nilai bobot untuk setiap atribut, kemudian dilanjutkan dengan proses perangkingan yang akan menyeleksi alternatif terbaik dari sejumlah alternatif. Dalam hal ini alternatif yang dimaksud adalah yang akan diterima sebagai staf berdasarkan kriteria-kriteria yang telah ditentukan. Sehingga diharapkan sistem akan dapat menghasilkan calon staf yang memiliki kualifikasi yang sesuai dengan kebutuhan lembaga STMIK Cipta Darma Surakarta.

Menurut Alter 'Sistem Pendukung Keputusan merupakan sistem informasi interaktif yang menyediakan informasi, pemodelan, dan pemanipulasian data. Sistem itu digunakan untuk membantu pengambilan keputusan dalam situasi yang semistruktur dan situasi yang terstruktur, dimana tidak seorang pun tahu secara pasti bagaimana keputusan seharusnya dibuat'. Sistem Pendukung Keputusan biasanya dibangun untuk mendukung solusi atas suatu masalah atau untuk mengevaluasi suatu peluang. Sistem Pendukung Keputusan yang seperti itu disebut dengan Aplikasi DSS. Aplikasi DSS digunakan dalam pengambilan keputusan. Aplikasi DSS menggunakan CBIS (Computer Based Information Systems) yang fleksibel, interaktif, dan dapat diadaptasi, yang dikembangkan untuk mendukung solusi atas masalah menajemen spesifik yang tidak terstruktur. Aplikasi DSS menggunakan data, memberikan antarmuka pengguna yang mudah, dan dapat menggabungkan pemikiran pengambil keputusan (Kusrini, 2007 : 15)[1]. Menurut Gorry dan Scott Morton dalam buku Turban $(2005 ; 19)$ Sistem Pendukung Keputusan adalah Sistem berbasis komputer interaktif, yang membantu para pengambil keputusan untuk menggunakan data dan berbagai model untuk memecahkan masalah-masalah tidak terstruktur [2].

Dari berbagai pengertian Sistem Pendukung Keputusan di atas, dapat disimpulkan bahwa Sistem Pendukung Keputusan adalah sebuah sistem yang berbasis komputer yang dapat membantu pengambilan keputusan untuk memecahkan masalah tertentu dengan memanfaatkan data dan model tertentu [2]. Metode Simple Additive Weighting (SAW) sering juga dikenal istilah metode penjumlahan terbobot. Konsep dasar metode SAW adalah mencari penjumlahan terbobot dari rating kinerja pada setiap alternatif pada semua atribut. Metode SAW membutuhkan proses normalisasi matriks keputusan $(X)$ ke suatu skala yang dapat diperbandingkan dengan semua rating alternatif yang ada[3].

Penelitian terkait dengan penggunaan metode SAW ini seperti pada tulisan Sri Eniyati dalam tulisannya Perancangan Sistem Pendukung Pengambilan Keputusan untuk Penerimaan Beasiswa dengan Metode SAW (Simple Additive Weighting), dalam menentukan penerimaan beasiswa, banyak sekali kriteria-kriteria yang harus dimiliki oleh individu sebagai syarat dalam mendapatkan beasiswa. Masing- masing sekolah pasti memiliki kriteria-kriteria untuk menentukan siapa yang akan terpilih untuk menerima beasiswa. Pembagian beasiswa dilakukan oleh beberapa lembaga untuk membantu seseorang yang kurang mampu ataupun berprestasi selama menempuh studinya. Untuk membantu penentuan dalam menetapkan seseorang yang layak menerima beasiswa maka dibutuhkan sebuah sistem pendukung keputusan. Pada penelitian ini akan diangkat suatu kasus yaitu mencari alternative terbaik bedasarkan kriteriakriteria yang telah ditentukan dengan menggunakan metode SAW (Simple Additive Weighting) Penelitian dilakukan dengan mencari nilai bobot untuk setiap atribut, kemudian dilakukan proses perankingan yang akan menentukan alternatif yang optimal, yaitu siswa terbaik[4].

\section{METODE}

Tahapan dalam pembuatan DSS dilakukan sebagai berikut:

1. Studi Kelayakan (Intelligence)

Pada langkah ini, sasaran ditentukan dan dilakukan pencarian prosedur, pengumpulan 
data, identifikasi masalah, identifikasi kepemilikan masalah, klasifikasi masalah, hingga akhirnya terbentuk sebuah pernyataan masalah tentang seleksi penerimaan staf baru.

\section{Perancangan (Design)}

Pada tahapan ini akan diformulasikan model diagram use case yang akan digunakan dan kriteria-kriteria yang ditentukan (pendidikan, usia, pengalaman kerja, nilai ipk, tes tertulis, tes wawancara dan status).

\section{Pemilihan (Choice)}

Setelah pada tahap design ditentukan perhitungan menggunakan metode simple additive weighting (SAW), nilai dan besaran angka pembobotannya. Penetapan kriteria yang digunakan untuk penilaian calon staf baru dihasilkan melalui rapat oleh tim dari departemen Pengembangan Sumber Daya Manusia (PSDM). Dari 7 (tujuh) kriteria yang ada, 5 kriteria (Pendidikan, usia, pengalaman kerja, nilai ipk dan status) dilakukan melalui seleksi pemberkasan. Jika pelamar lulus seleksi pemberkasan, selanjutnya dilakukan tes tertulis dan tes wawancara. Tahapan ini meliputi kegiatan pengerjaan soal pilihan ganda dan pengisian essay. Sebagai contoh, sebanyak 30 pelamar telah mengirimkan berkas pada saat proses penerimaan staf keuangan yang baru tahun 2019. Setelah penyeleksian berkas, selanjutnya pelamar yang diterima menjalani proses tes tertulis dan tes

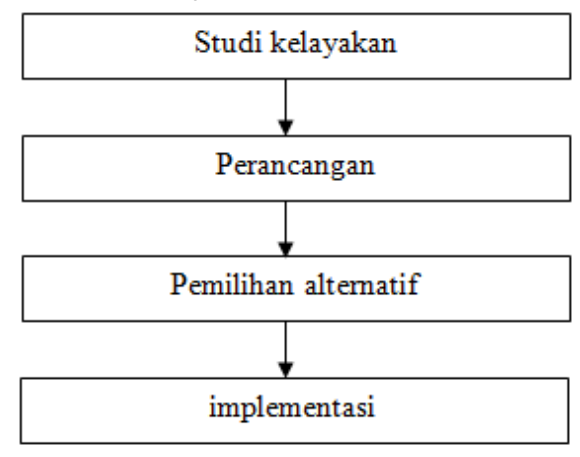

Gambar 2. Diagram alir penelitian

\section{HASIL}

\subsection{Analisis Kebutuhan Sistem}

Daftar kebutuhan sistem harus dibuat untuk memastikan sistem dapat memproses dan menghasilkan informasi sesuai dengan kebutuhan user. Kebutuhan fungsional sistem meliputi :
a. Log in
b. Input data

wawancara. Tes tertulis, pelamar menjawab soal pilihan ganda dan mengisi uraian (essay) pada laptop yang telah disediakan. Sejumlah laptop sewaan digunakan dalam proses ini. Selanjutnya tes wawancara yang secara langsung dilakukan oleh pegawai PSDM dengan pelamar. Proses tanya jawab ini akan menghasilkan nilai yang terkait aspek kecakapan dan kemampuan komunikasi pelamar.

4. Implementasi dan evaluasi

Setelah menentukan modelnya, tahap berikutnya adalah mengimplementasikannya dalam aplikasi DSS. Bahasa pemrogaman yang akan digunakan dalam pembuatan sistem pendukung keputusan ini adalah VB Net 6.0 dan database yang akan digunakan adalah MySQL. Pembuatan aplikasi dilakukan oleh programmer selama 2 bulan menggunakan laptop dari toko persewaan. Ketika aplikasi telah selesai dibuat, selanjutnya dijalankan dan diuji untuk melihat apakah sistem telah memenuhi kebutuhan, dengan melibatkan para pegawai PSDM. Proses ini meliputi pengaksesan sistem dan pengisian kuesioner oleh para koresponden. Dari hasil kuesioner, akan diperoleh hasil apakah sistem telah menghasilkan keluaran yang sesuai yaitu menampilkan calon staf yang sesuai dengan kriteria yang telah ditetapkan. Diagram alir penelitian seperti Gbr.1 : c. Pengolahan rekrutmen penerimaan staf

d. Hasil calon staf yang diterima

e. Persetujuan Kepala PSDM

Dari sisi kebutuhan non fungsional, meliputi :

a. Sistem diakses oleh user

b. Sistem dilengkapi dengan password pengaman, hanya user yang memiliki hak akses yang bisa masuk ke dalam sistem 


\subsection{Perhitungan Menggunakan Metode SAW} (Simple Additive Weighting)

Adapun langkah penyelesaian dalam menggunakan metode SAW dalam proses penerimaan staf di STMIK Cipta Darma Surakarta adalah:
1. Menentukan kriteria yang akan dijadikan acuan dalam pengambilan keputusan, yaitu $\mathrm{Cj}$. Terdapat 7 kriteria yang akan digunakan dalam proses rekrutmen yaitu

Tabel 1. Keterangan Kriteria yang digunakan

\begin{tabular}{|c|c|l|l|}
\hline No. & Kriteria & Keterangan & Jenis Kriteria \\
\hline 1 & C1 & Pendidikan & Benefit \\
\hline 2 & C2 & Usia & Benefit \\
\hline 3 & C3 & Pengalaman Kerja & Benefit \\
\hline 4 & C4 & Nilai IPK & Benefit \\
\hline 5 & C5 & Tes Tertulis & Benefit \\
\hline 6 & C6 & Tes Wawancara & Benefit \\
\hline 7 & C7 & Status & Cost \\
\hline
\end{tabular}

Kriteria yang tersaji di Tabel 1 diperoleh dari pengumpulan data di lapangan yaitu bagian PSDM STMIK Cipta Darma Surakarta. Kriteria tersebut merupakan kriteria yang digunakan dalam proses penilaian penerimaan staf baru.
2. Memberikan nilai bobot pada masingmasing kriteria dan menentukan bobot preferensi atau tingkat kepentingan (W) setiap kriteria. Pengambilan keputusan memberikan bobot untuk setiap kriteria berdasarkan kriteria yang diharuskan dalam penjabarannya pada tabel 2 :

Tabel 2. Bobot Kriteria

\begin{tabular}{|l|l|c|c|}
\hline No. & \multicolumn{1}{|c|}{ Kriteria } & Bobot & $\begin{array}{c}\text { Bobot } \\
\text { preferensi }\end{array}$ \\
\hline 1 & Pendidikan & $20 \%$ & 0,2 \\
\hline 2 & Usia & $20 \%$ & 0,2 \\
\hline 3 & Pengalaman Kerja & $10 \%$ & 0,1 \\
\hline 4 & Nilai IPK & $10 \%$ & 0,1 \\
\hline 5 & Tes Tertulis & $10 \%$ & 0,1 \\
\hline 6 & Tes Wawancara & $15 \%$ & 0,15 \\
\hline 7 & Status & $15 \%$ & 0,15 \\
\hline \multicolumn{2}{|c|}{ Total } & $100 \%$ & 1 \\
\hline
\end{tabular}

Tabel 3. Skala Nilai Kriteria

\begin{tabular}{|c|c|c|c|}
\hline No. & kriteria & Skala penilaian & Bobot Nilai \\
\hline \multirow[t]{2}{*}{1} & \multirow{2}{*}{ pendidikan } & S1 & 1 \\
\hline & & D3 & 0,8 \\
\hline \multirow[t]{3}{*}{2} & \multirow[t]{3}{*}{ usia } & 17 tahun -20 tahun (muda) & 0,4 \\
\hline & & 21 tahun -25 tahun (sedang) & 1 \\
\hline & & 26 tahun -30 tahun (tua) & 0,6 \\
\hline \multirow[t]{2}{*}{3} & \multirow{2}{*}{$\begin{array}{l}\text { Pengalaman } \\
\text { kerja }\end{array}$} & 0 tahun & 0,8 \\
\hline & & $>1$ tahun & 1 \\
\hline \multirow[t]{2}{*}{4} & \multirow[t]{2}{*}{ nilai ipk } & $<3,00$ & 0,7 \\
\hline & & $>3,01$ & 1 \\
\hline \multirow[t]{2}{*}{5} & \multirow[t]{2}{*}{ tes tertulis } & $>80$ & 1 \\
\hline & & $<79$ & 0,7 \\
\hline \multirow[t]{2}{*}{6} & \multirow{2}{*}{$\begin{array}{l}\text { tes } \\
\text { wawancara }\end{array}$} & $>80$ & 1 \\
\hline & & $<79$ & 0,7 \\
\hline
\end{tabular}




\begin{tabular}{|l|l|c|c|}
\hline 7 & Status & Single & 1 \\
\cline { 3 - 4 } & & Menikah & 0,8 \\
\hline
\end{tabular}

3. Membuat tabel rating kecocokan dari setiap alternatif pada setiap kriteria. Ada 8 orang calon staf yang dinilai, yaitu :
a. Umi (A1)
b. Norma (A2)
c. Aprilia (A3)
d. $\operatorname{Remi}(\mathrm{A} 4)$
e. Novia (A5)
f. Natalia(A6)

g. Vita (A7)

h. Reyna (A8)

Berdasarkan seleksi berkas dan tes yang dilakukan bagian PSDM STMIK Cipta Darma Surakarta terhadap calon staf, diperoleh data penilaian dan rating kecocokan dari setiap alternatif (Ai) pada setiap kriteria ( $\mathrm{Ci})$.

Tabel 4. Data Penilaian

\begin{tabular}{|l|l|c|l|c|c|c|c|l|}
\hline No & nama & pendidikan & usia & $\begin{array}{l}\text { pengalaman } \\
\text { kerja }\end{array}$ & $\begin{array}{l}\text { nilai } \\
\text { ipk }\end{array}$ & $\begin{array}{l}\text { tes } \\
\text { tertulis }\end{array}$ & wawancara & status \\
\hline 1 & umi & $\mathrm{d} 3$ & 23 & 1 & 2,9 & 88 & 92 & menikah \\
\hline 2 & norma & $\mathrm{s} 1$ & 21 & 1 & 3,5 & 90 & 80 & single \\
\hline 3 & aprilia & $\mathrm{s} 1$ & 22 & 0 & 2,75 & 90 & 90 & menikah \\
\hline 4 & remi & $\mathrm{s} 1$ & 20 & 0 & 3 & 95 & 89 & single \\
\hline 5 & novia & $\mathrm{d} 3$ & 24 & 1 & 3,8 & 96 & 70 & single \\
\hline 6 & natalia & $\mathrm{d} 3$ & 25 & 0 & 3,25 & 94 & 88 & menikah \\
\hline 7 & vita & $\mathrm{s} 1$ & 26 & 1 & 3,55 & 89 & 93 & menikah \\
\hline 8 & reyna & $\mathrm{d} 3$ & 23 & 1 & 3,72 & 93 & 97 & menikah \\
\hline
\end{tabular}

4. Membuat matrik keputusan $(X)$ yang dibentuk dari tabel rating kecocokan dari setiap alternatif pada setiap kriteria.

Tabel 5. Nilai Rating Kecocokan

\begin{tabular}{|l|c|c|c|c|c|c|c|}
\hline \multicolumn{1}{|c|}{ nama } & C1 & C2 & C3 & C4 & C5 & C6 & C7 \\
\hline umi & 0,8 & 1 & 1 & 0,7 & 1 & 1 & 0,8 \\
\hline norma & 1 & 1 & 1 & 1 & 1 & 1 & 1 \\
\hline aprilia & 1 & 1 & 0,8 & 0,7 & 1 & 1 & 0,8 \\
\hline remi & 1 & 0,4 & 0,8 & 1 & 1 & 1 & 1 \\
\hline novia & 0,8 & 1 & 1 & 1 & 1 & 0,7 & 1 \\
\hline
\end{tabular}




\begin{tabular}{|c|c|c|c|c|c|c|c|}
\hline natalia & 0,8 & 1 & 0,8 & 1 & 1 & 1 & $0, \varepsilon$ \\
\hline vita & 1 & 0,6 & 1 & 1 & 1 & 1 & 0,8 \\
\hline reyna & 0,8 & 1 & 1 & 1 & 1 & 1 & $0, \varepsilon$ \\
\hline $\mathrm{Ai} / \mathrm{Ci}$ & $\mathrm{C} 1$ & C2 & C3 & $\mathrm{C} 4$ & $\mathrm{C} 5$ & C6 & C7 \\
\hline $\mathrm{A} 1$ & 0,8 & 1 & 1 & 0,7 & 1 & 1 & 0,8 \\
\hline $\mathrm{A} 2$ & 1 & 1 & 1 & 1 & 1 & 1 & 1 \\
\hline A3 & 1 & 1 & 0,8 & 0,7 & 1 & 1 & 0,8 \\
\hline A4 & 1 & 0,4 & 0,8 & 1 & 1 & 1 & 1 \\
\hline A5 & 0,8 & 1 & 1 & 1 & 1 & 0,7 & 1 \\
\hline A6 & 0,8 & 1 & 0,8 & 1 & 1 & 1 & 0,8 \\
\hline A7 & 1 & 0,6 & 1 & 1 & 1 & 1 & 0,8 \\
\hline A8 & 0,8 & 1 & 1 & 1 & 1 & 1 & 0,8 \\
\hline
\end{tabular}

Dari tabel nilai rating kecocokan, dibuat sebuat tabel yang menunjukkan matriks awal dari nilai alternatif berdasarkan skala nilai yang ditentukan, seperti Tabel 6.

Tabel 6. Matriks Awal

Sesudah mendapatkan matriks awal selanjutnya melakukan normalisasi keputusan (Xij) dengan menghitung nilai rating kinerja ternormalisasi
(Rij) dari alternatif (Ai) pada setiap kriteria (Ci) berdasarkan persamaan di metode SAW yaitu: jika $j$ adalah biaya (cost) 
$R i j\left\{\begin{array}{c}\frac{X i j}{M a x X i j} j i k a j \text { adalah keuntungan (benefit) } \\ \frac{\text { MinXij }}{X i j} \text { jika } j \text { adalah biaya (cost) }\end{array}\right.$

Keterangan :

$\mathrm{Ri} \mathrm{j}=$ nilai rating kinerja ternormalisasi

$\mathrm{Xi}=$ nilai atribut yang dimiliki dari setiap kriteria

Max xij = nilai terbesar dari setiap kriteria $\mathrm{i}$

Min $x i j=$ nilai terkecil dari setiap kriteria $i$

Benefit $=$ jika nilai terbesar adalah terbaik

Cost $=$ jika nilai terkecil adalah terbaik

1. Kriteria Pendidikan, termasuk atribut keuntungan (benefit)

$$
\begin{aligned}
& \mathrm{R} 1.1=\frac{0,8}{\max \{0,8 ; 1 ; 1 ; 1 ; 0,8 ; 0,8 ; 1 ; 0,8\}}=\frac{0,8}{1}=0,8 \\
& \mathrm{R} 2.1=\frac{1}{\max \{0,8 ; 1 ; 1 ; 1 ; 0,8 ; 0,8 ; 1 ; 0,8\}}=\frac{1}{1}=1 \\
& \mathrm{R} 3.1=\frac{1}{\max \{0,8 ; 1 ; 1 ; 1 ; 0,8 ; 0,8 ; 1 ; 0,8\}}=\frac{1}{1}=1 \\
& \mathrm{R} 4.1=\frac{1}{\max \{0,8 ; 1 ; 1 ; 1 ; 0,8 ; 0,8 ; 1 ; 0,8\}}=\frac{1}{1}=1 \\
& \mathrm{R} 5.1=\frac{0,8}{\max \{0,8 ; 1 ; 1 ; 1 ; 0,8 ; 0,8 ; 1 ; 0,8\}}=\frac{0,8}{1}=0,8 \\
& \mathrm{R} 6.1=\frac{0,8}{\max \{0,8 ; 1 ; 1 ; 1 ; 0,8 ; 0,8 ; 1 ; 0,8\}}=\frac{0,8}{1}=0,8 \\
& \mathrm{R} 7.1=\frac{1}{\max \{0,8 ; 1 ; 1 ; 1 ; 0,8 ; 0,8 ; 1 ; 0,8\}}=\frac{1}{1}=1 \\
& \mathrm{R} 8.1=\frac{0,8}{\max \{0,8 ; 1 ; 1 ; 1 ; 0,8 ; 0,8 ; 1 ; 0,8\}}=\frac{0,8}{1}=0,8
\end{aligned}
$$

2. Kriteria usia, termasuk atribut keuntungan (benefit)

$$
\begin{aligned}
& \mathrm{R} 1.2=\frac{1}{\max \{1 ; 1 ; 1 ; 0,4 ; 1 ; 1 ; 0,6 ; 1\}}=\frac{1}{1}=1 \\
& \mathrm{R} 2.2=\frac{1}{\max \{1 ; 1 ; 1 ; 0,4 ; 1 ; 1 ; 0,6 ; 1\}}=\frac{1}{1}=1 \\
& \mathrm{R} 3.2=\frac{1}{\max \{1 ; 1 ; 1 ; 0,4 ; 1 ; 1 ; 0,6 ; 1\}}=\frac{1}{1}=1 \\
& \mathrm{R} 4.2=\frac{0,4}{\max \{1 ; 1 ; 1 ; 0,4 ; 1 ; 1 ; 0,6 ; 1\}}=\frac{0,4}{1}=0,4 \\
& \mathrm{R} 5.2=\frac{1}{\max \{1 ; 1 ; 1 ; 0,4 ; 1 ; 1 ; 0,6 ; 1\}}=\frac{1}{1}=1 \\
& \mathrm{R} 6.2=\frac{1}{\max \{1 ; 1 ; 1 ; 0,4 ; 1 ; 1 ; 0,6 ; 1\}}=\frac{1}{1}=1 \\
& \mathrm{R} 7.2=\frac{0,7}{\max \{1 ; 1 ; 1 ; 0,4 ; 1 ; 1 ; 0,6 ; 1\}}=\frac{0,7}{1}=0,7
\end{aligned}
$$


$\mathrm{R} 8.2=\frac{1}{\max \{1 ; 1 ; 1 ; 0,4 ; 1 ; 1 ; 0,6 ; 1\}}=\frac{1}{1}=1$

3. Kriteria pengalaman kerja, termasuk atribut keuntungan (benefit)

$$
\begin{aligned}
& \mathrm{R} 1.3=\frac{1}{\max \{1 ; 1 ; 0,8 ; 0,8 ; 1 ; 0,8 ; 1 ; 1\}}=\frac{1}{1}=1 \\
& \mathrm{R} 2.3=\frac{1}{\max \{1 ; 1 ; 0,8 ; 0,8 ; 1 ; 0,8 ; 1 ; 1\}}=\frac{1}{1}=1 \\
& \mathrm{R} 3.3=\frac{0,8}{\max \{1 ; 1 ; 0,8 ; 0,8 ; 1 ; 0,8 ; 1 ; 1\}}=\frac{0,8}{1}=0,8 \\
& \mathrm{R} 4.3=\frac{0,8}{\max \{1 ; 1 ; 0,8 ; 0,8 ; 1 ; 0,8 ; 1 ; 1\}}=\frac{0,8}{1}=0,8 \\
& \mathrm{R} 5.3=\frac{1}{\max \{1 ; 1 ; 0,8 ; 0,8 ; 1 ; 0,8 ; 1 ; 1\}}=\frac{1}{1}=1 \\
& \mathrm{R} 6.3=\frac{0,8}{\max \{1 ; 1 ; 0,8 ; 0,8 ; 1 ; 0,8 ; 1 ; 1\}}=\frac{0,8}{1}=0,8 \\
& \mathrm{R} 7.3=\frac{1}{\max \{1 ; 1 ; 0,8 ; 0,8 ; 1 ; 0,8 ; 1 ; 1\}}=\frac{1}{1}=1 \\
& \mathrm{R} 8.3=\frac{1}{\max \{1 ; 1 ; 0,8 ; 0,8 ; 1 ; 0,8 ; 1 ; 1\}}=\frac{1}{1}=1
\end{aligned}
$$

4. Kriteria nilai ipk, termasuk atribut keuntungan (benefit)

$$
\begin{aligned}
& \mathrm{R} 1.4=\frac{0,7}{\max \{0,7 ; 1 ; 0,7 ; 1 ; 1 ; 1 ; 1 ; 1\}}=\frac{0,7}{1}=0,7 \\
& \mathrm{R} 2.4=\frac{1}{\max \{0,7 ; 1 ; 0,7 ; 1 ; 1 ; 1 ; 1 ; 1\}}=\frac{1}{1}=1 \\
& \mathrm{R} 3.4=\frac{0,7}{\max \{0,7 ; 1 ; 0,7 ; 1 ; 1 ; 1 ; 1 ; 1\}}=\frac{1}{1}=0,7 \\
& \mathrm{R} 4.4=\frac{1}{\max \{0,7 ; 1 ; 0,7 ; 1 ; 1 ; 1 ; 1 ; 1\}}=\frac{1}{1}=1 \\
& \mathrm{R} 5.4=\frac{1}{\max \{0,7 ; 1 ; 0,7 ; 1 ; 1 ; 1 ; 1 ; 1\}}=\frac{1}{1}=1 \\
& \mathrm{R} 6.4=\frac{1}{\max \{0,7 ; 1 ; 0,7 ; 1 ; 1 ; 1 ; 1 ; 1\}}=\frac{1}{1}=1 \\
& \mathrm{R} 7.4=\frac{1}{\max \{0,7 ; 1 ; 0,7 ; 1 ; 1 ; 1 ; 1 ; 1\}}=\frac{1}{1}=1 \\
& \mathrm{R} 8.4=\frac{1}{\max \{0,7 ; 1 ; 0,7 ; 1 ; 1 ; 1 ; 1 ; 1\}}=\frac{1}{1}=1
\end{aligned}
$$

5. Kriteria tes tertulis, termasuk atribut keuntungan (benefit)

$$
\begin{aligned}
& \mathrm{R} 1.5=\frac{1}{\max \{1 ; 1 ; 1 ; 1 ; 1 ; 1 ; 1 ; 1\}}=\frac{1}{1}=1 \\
& \mathrm{R} 2.5=\frac{1}{\max \{1 ; 1 ; 1 ; 1 ; 1 ; 1 ; 1 ; 1\}}=\frac{1}{1}=1
\end{aligned}
$$


$\mathrm{R} 3.5=\frac{1}{\max \{1 ; 1 ; 1 ; 1 ; 1 ; 1 ; 1 ; 1\}}=\frac{1}{1}=1$

$\mathrm{R} 4.5=\frac{1}{\max \{1 ; 1 ; 1 ; 1 ; 1 ; 1 ; 1 ; 1\}}=\frac{1}{1}=1$

$\mathrm{R} 5.5=\frac{1}{\max \{1 ; 1 ; 1 ; 1 ; 1 ; 1 ; 1 ; 1\}}=\frac{1}{1}=1$

$\mathrm{R} 6.5=\frac{1}{\max \{1 ; 1 ; 1 ; 1 ; 1 ; 1 ; 1 ; 1\}}=\frac{1}{1}=1$

$\mathrm{R} 7.5=\frac{1}{\max \{1 ; 1 ; 1 ; 1 ; 1 ; 1 ; 1 ; 1\}}=\frac{1}{1}=1$

$\mathrm{R} 8.5=\frac{1}{\max \{1 ; 1 ; 1 ; 1 ; 1 ; 1 ; 1 ; 1\}}=\frac{1}{1}=1$

6. Kriteria tes wawancara, termasuk atribut keuntungan (benefit)
R1.6 $=\frac{1}{\max \{1 ; 1 ; 1 ; 1 ; 0,7 ; 1 ; 1 ; 1\}}=\frac{1}{1}=1$
$\mathrm{R} 2.6=\frac{1}{\max \{1 ; 1 ; 1 ; 1 ; 0,7 ; 1 ; 1 ; 1\}}=\frac{1}{1}=1$
R3.6 $=\frac{1}{\max \{1 ; 1 ; 1 ; 1 ; 0,7 ; 1 ; 1 ; 1\}}=\frac{1}{1}=1$
R4.6 $=\frac{1}{\max \{1 ; 1 ; 1 ; 1 ; 0,7 ; 1 ; 1 ; 1\}}=\frac{1}{1}=1$
R5.6 $=\frac{0,7}{\max \{1 ; 1 ; 1 ; 1 ; 0,7 ; 1 ; 1 ; 1\}}=\frac{0,7}{1}=0,7$
R6.6 $=\frac{1}{\max \{1 ; 1 ; 1 ; 1 ; 0,7 ; 1 ; 1 ; 1\}}=\frac{1}{1}=1$
R7.6 $=\frac{1}{\max \{1 ; 1 ; 1 ; 1 ; 0,7 ; 1 ; 1 ; 1\}}=\frac{1}{1}=1$

7. Kriteria status, termasuk atribut biaya(cost)
$\mathrm{R} 1.7=\frac{\min \{0,8 ; 1 ; 0,8 ; 1 ; 1 ; 0,8 ; 0,8 ; 0,8\}}{0,8}=\frac{0,8}{0,8}=1$
$\mathrm{R} 2.7=\frac{\min \{0,8 ; 1 ; 0,8 ; 1 ; 1 ; 0,8 ; 0,8 ; 0,8\}}{1}=\frac{0,8}{1}=0,8$
R3.7 $=\frac{\min \{0,8 ; 1 ; 0,8 ; 1 ; 1 ; 0,8 ; 0,8 ; 0,8\}}{0,8}=\frac{0,8}{0,8}=1$
R4.7 $=\frac{\min \{0,8 ; 1 ; 0,8 ; 1 ; 1 ; 0,8 ; 0,8 ; 0,8\}}{1}=\frac{0,8}{1}=0,8$
R5.7 $=\frac{\min \{0,8 ; 1 ; 0,8 ; 1 ; 1 ; 0,8 ; 0,8 ; 0,8\}}{1}=\frac{0,8}{1}=0,8$
$\mathrm{R} 6.7=\frac{\min \{0,8 ; 1 ; 0,8 ; 1 ; 1 ; 0,8 ; 0,8 ; 0,8\}}{0,8}=\frac{0,8}{0,8}=1$ 
$\mathrm{R} 7.7=\frac{\min \{0,8 ; 1 ; 0,8 ; 1 ; 1 ; 0,8 ; 0,8 ; 0,8\}}{0,8}=\frac{0,8}{0,8}=1$

$\mathrm{R} 8.7=\frac{\min \{0,8 ; 1 ; 0,8 ; 1 ; 1 ; 0,8 ; 0,8 ; 0,8\}}{0,8}=\frac{0,8}{0,8}=1$

Tabel 7. Matriks Normalisasi

\begin{tabular}{|c|c|c|c|c|c|c|c|}
\hline $\mathrm{Ai}$ & $\mathrm{C} 1$ & C2 & $\mathrm{C} 3$ & $\mathrm{C} 4$ & $\mathrm{C} 5$ & $\mathrm{C} 6$ & $\mathrm{C} 7$ \\
\hline A & 0,8 & 1 & 1 & 0,7 & 1 & 1 & 1,00 \\
\hline B & 1 & 1 & 1 & 1 & 1 & 1 & 0,80 \\
\hline C & 1 & 1 & 0,8 & 0,7 & 1 & 1 & 1,00 \\
\hline D & 1 & 0,4 & 0,8 & 1 & 1 & 1 & 0,80 \\
\hline $\mathrm{E}$ & 0,8 & 1 & 1 & 1 & 1 & 0,7 & 0,80 \\
\hline $\mathrm{F}$ & 0,8 & 1 & 0,8 & 1 & 1 & 1 & 1,00 \\
\hline G & 1 & 0,6 & 1 & 1 & 1 & 1 & 1,00 \\
\hline $\mathrm{H}$ & 0,8 & 1 & 1 & 1 & 1 & 1 & 1,00 \\
\hline
\end{tabular}

Hasil yang diperoleh dari setiap kriteria yang ternormalisasi (Ri), kemudian menentukan hasil nilai akhir (Vi) yang diperoleh dari penjumlahan dan perkalian elemen (Ri) dengan nilai bobot (W).

$$
\begin{aligned}
& \mathrm{V} 1=(0,8 * 0,2)+(1 * 0,2)+(1 * 0,1)+(1 * 0,1)+(0,7 * 0,1)+(1 * 0,15)+(1 * 0,15) \\
& =0,16+0,2+0,1+0,1+0,07+0,15+0,15=0,93 \\
& \mathrm{~V} 2=(1 * 0,2)+(1 * 0,2)+(1 * 0,1)+(1 * 0,1)+(1 * 0,1)+(1 * 0,15)+(0,8 * 0,15) \\
& =0,2+0,2+0,1+0,1+0,1+0,15+0,12=0,97 \\
& \mathrm{~V} 3=(1 * 0,2)+(1 * 0,2)+(0,8 * 0,1)+(0,7 * 0,1)+(1 * 0,1)+(1 * 0,15)+(1 * 0,15) \\
& =0,2+0,2+0,08+0,1+0,07+0,1+0,15=0,95 \\
& \mathrm{~V} 4=(1 * 0,2)+(0,4 * 0,2)+(0,8 * 0,1)+(1 * 0,1)+(1 * 0,1)+(1 * 0,15)+(0,8 * 0,15) \\
& =0,2+0,08+0,08+0,1+0,1+0,15+0,12=0,83
\end{aligned}
$$

$$
\begin{aligned}
\mathrm{V} 6 & =(0,8 * 0,2)+(1 * 0,2)+(0,8 * 0,1)+(1 * 0,1)+(1 * 0,1)+(1 * 0,15)+(1 * 0,15) \\
& =0,16+0,2+0,08+0,1+0,1+0,15+0,15=0,94
\end{aligned}
$$

$$
\begin{aligned}
\mathrm{V} 7 & =(1 * 0,2)+(0,6 * 0,2)+(1 * 0,1)+(1 * 0,1)+(1 * 0,1)+(1 * 0,15)+(1 * 0,15) \\
& =0,2+0,12+0,1+0,1+0,1+0,15+0,15=0,92
\end{aligned}
$$

$$
\begin{aligned}
\mathrm{V} 8 & =(0,8 * 0,2)+(1 * 0,2)+(1 * 0,1)+(1 * 0,1)+(1 * 0,1)+(1 * 0,15)+(1 * 0,15) \\
& =0,16+0,2+0,1+0,1+0,1+0,15+0,15=0,96
\end{aligned}
$$

Kriteria yang digunakan sebagai dasar penilaian terhadap seleksi penerimaan staf baru yang memiliki angka paling besar adalah pendidikan (20\%) dan usia (20\%), selanjutnya tes wawancara dan status masing-masing $15 \%$, pengalaman kerja, nilai ipk dan tes tertulis masing-masing sebesar $15 \%$, dan pengalaman kerja serta inisiatif http://ejournal.urindo.ac.id/index.php/TI diberikan bobot masing-masing sebesar $20 \%$. Berdasarkan nilai akhir, dapat diurutkan nama calon staf yang akan diterima sesuai ranking nilanya, mulai dari nilai tertinggi hingga terendah, yaitu V2/Norma sebesar 0,93, V8/Reyna sebesar $0,96, \mathrm{~V} 3 /$ Aprilia sebesar $0,95, \mathrm{~V} 6 /$ Natalia sebesar 0,94, V1/Umi sebesar 0,93, V7/Vita sebesar 0,92, 
V5/Novia sebesar 0,89 dan V4/Remi sebesar 0,83. Dapat disimpulkan bahwa hasil yang diperoleh dapat memunculkan nama berdasarkan peringkat nilai tertinggi dari kriteria yang telah ditentukan, sehingga membantu pihak PSDM dalam menentukan nama calon staf yang akan diterima (Norma).

\section{SIMPULAN}

Berdasarkan hasil pembahasan terkait penerapan metode SAW dalam rekrutmen penerimaan staf di STMIK Cipta Darma Surakarta, maka dapat diperoleh kesimpulan penelitian sebagai berikut:

1. Metode Simple Additive Weigthing (SAW) dapat digunakan untuk menghitung dan menghasilkan urutan nilai hasil dalam proses seleksi penerimaan staf, sehingga membantu bagian PSDM STMIK Cipta Darma Surakarta dalam menentukan nama calon staf yang akan diterima.

2. Perancangan sistem rekrutmen penerimaan staf ini diharapkan dapat dijadikan gambaran informasi mengenai kriteria apa saja yang di pakai dalam menilai calon staf yang sesuai dengan kebutuhan lembaga, berapa bobot nilai yang dipakai dan bagaimana hasil yang diperoleh berdasar proses perhitungan.

\section{DAFTAR PUSTAKA}

[1]. Kusrini. Konsep dan Aplikasi Sistem Pendukung Keputusan. Andi Offset. Yogyakarta. 2007.

[2]. Anjar Wanto, Hamonangan Damanik. Analisis Penerapan Sistem Pendukung Keputusan Terhadap Seleksi Penerima Beasiswa BBM (Bantuan Belajar Mahasiswa) Pada Perguruan Tinggi Menggunakan Metode Simple Additive Weighting (SAW) Studi Kasus : AMIK Tunas Bangsa Pematangsiantar). Prosiding Seminar Nasional Rekayasa (SNTR) II Volume (2) 25 November 2015, ISSN : 2407- 735 
[3]. Ismanto, Edi,; Effendi ,Noverta. Sistem Pendukung Keputusan Penerimaan Karyawan Dengan Metode Simple Additive Weighting (SAW). PROSIDING Vol 1-Sep 2016, 1th Celscitech-UMRI 2016 ISSN: 25413023, LP2M-UMRI.

[4]. Eniyati, Sri. Perancangan Sistem Pendukung Pengambilan Keputusan untuk Penerimaan Beasiswa dengan Metode SAW (Simple Additive Weighting). Jurnal Teknologi Informasi DINAMIK Volume 16, No.2, Juli 2011 : 17117, ISSN : 08549524. 